Italy

\title{
Health monitoring endangered at Séveso
}

THE lack of facilities available to local scientists for monitoring the health of people exposed to $2,3,7,8$-tetrachlorodibenzo-p-dioxin (dioxin) at the Italian town of Séveso in July 1976 is endangering the health surveillance programme.

This is just one of the conclusions reported in the minutes of the International Steering Committee (ISC) of the Lombardy region's special office for Séveso. The ISC - composed in the main of internationally renowned scientists was formed in the wake of the Séveso accident to consider the implications of exposure to dioxin by the local population.

To save the health surveillance programme, the ISC says it is of crucial importance for either local or national government to make a commitment to establish more permanent staffing within an epidemiological group set up specifically for the "Séveso follow-up". And in order to overcome the disillusion of local doctors in the current surveillance exercise, the ISC consider that one of the first priorities of the epidemiological group must be to enhance the motivation and to increase the involvement of local medical practitioners and hospital staff in a longterm programme.

It is the view of the ISC that the skin disease chloracne is one of the best indications of exposure to dioxin. Individuals with chloracne, it says, represent a group "for whom biologically significant (as distinct from presumed) exposure [to dioxin] can be reasonably accepted". The ISC believes that it is this group which faces the greatest health risk and which should be monitored for many years, perhaps even for life. To assess the risks for this sector (a group composed entirely of children) it is suggested that two matching control groups - one not exposed to dioxin, and the other possibly exposed - should also be monitored.

Dioxin is known to be both a teratogen and a carcinogen in animals. Data on the danger it poses to the human fetus are simply not available. However, the ISC acknowledges that there may still be longterm risks to the fetus of "chronic exposure to very small amounts" of dioxin and the committee recommends that a registry be kept of severe and minor congenital malformations; birth weight; prenatal and postnatal mortality rates; and the rate of spontaneous abortions.

An efficient cancer registry based on morbidity as well as mortality is also urgently required says the committee. Maintenance of such a registry is both difficult and time consuming, but the ISC points out that many countries carry out such programmes.

Over 1,000 individuals employed in the chemical industry are known to have been exposed to significant levels of dioxin over the last 30 years and the committee is anxious to obtain any information about their health problems. The ISC says that this information will help the Italian authorities to assess the adequacy of the health programmes for the Séveso area.

Failure to implement these proposals will mean that much information, important to the well being of the Séveso population, will be lost. If the ISC recommendations are ignored, many of the scientists on it could withdraw.

Alastair Hay

\section{Eastern Europe}

\section{Scientific exchanges are needed for détente}

SCIENTIFIC exchanges "agreed by treaty"should continue, irrespective of developments in Afghanistan, according to East German radio last week.

East Germany has a special interest in preserving détente at this stage - the first ever formal summit between Party Leader Erich Honecker and the West German Chancellor Helmut Schmidt is expected this spring. However, political spokespersons and commentators throughout the socialist bloc seem to be making a concerted effort to minimise the effect of the Soviet intervention in Afghanistan on détente in Europe.

Eastern hopes in this regard have undoubtedly been bolstered by the slow response of Western European governments in support of Carter's measures. The UK, for example, will hold a Cabinet Office meeting later this week to discuss British action (if any). An environmental working party is currently in Moscow, discussing odour prevention, under the auspices of the Intergovernmental Joint Commission for Trade and Technology. According to a representative of the Department of Trade, the meeting was probably allowed to continue because no member of the British delegation was of sufficiently high rank to warrant its cancellation at this stage.

Accordingly, while denying that the
Soviet Union has, in fact, done anything untoward in sending forces into Afghanistan, the socialist bloc commentators continue to urge détente. "Economic, scientific, technical and cultural links between countries", said Viktor Glazunev, one of Moscow Radio's chief "news analysts", "make up what you might call the material fabric of détente. A blow at the fabric strikes a blow at détente itself ...."

The need to bolster détente is all the more urgent, with the Hamburg Scientific Forum only a month away. This forum is intended to be a meeting point for individual scientists to discuss problems in the context of East-West scientific cooperation, including contacts, communication and the exchange of information. Clearly world events, and the general issues of academic freedom and human rights are bound to be raised in that context.

Indeed, one human rights lobby, led by Valentin Turchin, and John Macdonald Q.C., would have suggested that western delegates should press for the forum to be postponed, until such time as the dissident physicist, Yurii Orlov, is released from strict regime labour camp. (The rationale of their argument being that Orlov, convicted in 1978 of slandering the Soviet state, had, in fact, been collecting material on alleged Soviet breaches of the Helsinki accords, in his role as founder member of the clandestine Helsinki Monitoring Group in Moscow.)

Other action groups, while agreeing that the forum should take place, see it as a valuable platform for human rights. "In our opinion", says the Scientific and Medical Committee for Soviet Jewry, "for the exercise to be meaningful, not only should the Hamburg meeting include on its agenda the question of the freedom of the movement of scientists; also any scientific body must ensure that a clause dealing with this problem is written into its constitution."

This too is essentially the attitude taken by Bruce Kiernan, human rights coordinator of the American Association for the Advancement of Science, which, together with the Committee of Concerned Scientists will be holding a human rights' briefing for the US delegates to Hamburg early in February.

Those French scientists that are concerned with human rights have not yet made a formal statement; it is understood, however, that they will press for the guaranteeing of the personal security of scientists as an indispensible preliminary to any international cooperation - and that, the Helsinki accords being indivisible, it is impossible to dissociate "exchange programmes" from human rights.

Vera Rich 